\title{
ANALISIS KESADARAN MATEMATIS SISWA DALAM PEMBELAJARAN SNOW CUBE THROWING BERBASIS EKSPLORASI
}

\author{
Nenden Mutiara Sari \\ Universitas Pasundan \\ nenden.mutiara@unpas.ac.id
}

\begin{abstract}
ABSTRAK
Model pembelajaran snow cube throwing dikembangkan dengan tujuan agar siswa menghargai kegunaan matematika dalam kehidupan sehari-hari. Sesuai dengan kekhasan model pembelajaran ini, siswa diberikan berbagai jenis bahan ajar kontekstual yang bertujuan agar siswa memiliki kesadaran matematis yang baik. Penelitian ini bertujuan menganalisis kesadaran matematis siswa yang memperoleh pembelajaran snow cube throwing berbasis eksplorasi (SCTBE) ditinjau berdasarkan kategori sekolah. Penelitian ini merupakan penelitian mix-method dengan rancangan sekuensial eksplanatoris. Subjek penelitian adalah siswa kelas VIII dari tiga sekolah di Kota Cimahi. Instrumen yang digunakan untuk dalam penelitian ini yaitu instrument non tes angket kesadaran matematis. Analisis data yang dilakukan adalah dengan uji perbedaan rerata antar kelompok.Hasil penelitian menunjukkan bahwa: (1) pembelajaran SCTBE memberikan dampak yang sama terhadap kesadaran matematis siswa pada setiap kategori sekolah. Dengan kata lain, seluruh siswa yang memperoleh pembelajaran SCTBE memiliki kesadaran yang sama akan kegunaan matematika dalam kehidupan sehari-hari, studi masa depan dan juga karir; dan (2) Hasil analisis pada setiap indikator menunjukkan bahwa kesadaran matematis siswa pada setiap kategori sekolah sudah tergolong baik.
\end{abstract}

Kata Kunci : kesadaran matematis, model pembelajaran snow cube throwing, pembelajaran eksploratif.

\begin{abstract}
The snow cube throwing learning model was developed with the aim of making students appreciate the usefulness of mathematics in everyday life. In accordance with the characteristics of this learning model, students are given various types of contextual teaching materials that aim to make students have good mathematical awareness. This study aims to analyze the mathematical awareness of students who receive snow cube throwing (SCTBE) learning based on exploration in terms of school categories. This study is a mix-method study with an explanatory sequential design. The research subjects were students of class VIII from three schools in Cimahi City. The results showed that: (1) SCTBE learning had the same impact on students' mathematical awareness in each school category. In other words, all students who receive SCTBE learning have the same awareness of the usefulness of mathematics in daily life, future studies and careers; and (2) The results of the analysis on each indicator show that the students' mathematical awareness in each school category is classified as good.
\end{abstract}

Keywords: exploration learning, mathematical awareness, snow cube throwing learning model. 


\section{PENDAHULUAN}

Elfiky (2009) dalam bukunya Quwwat Al-Tafkir atau terapi berpikir positif, menuliskan tujuh aspek penting dalam kehidupan yaitu: aspek spiritual, kesehatan, kepribadian, keluarga, sosial, profesi dan material. Matematika memiliki peranan penting dalam ke tujuh aspek tersebut. Sebagai contoh dalam aspek spiritual, bagi umat islam dalam Al-Quran dijelaskan bahwa "Barang siapa membawa amal yang baik, maka baginya pahala sepuluh kali lipat amalnya; dan barang siapa yang membawa perbuatan jahat maka ia tidak diberi pembalasan melainkan seimbang dengan kejahatannya, sedang mereka sedikitpun tidak dianiaya dirugikan" (QS. Al-An'am: 160)”. Dalam matematika hal ini berkaitan dengan konsep kelipatan suatu bilangan. Untuk memahami hal tersebut, seseorang setidaknya harus memiliki kemampuan dasar matematika.

Aspek lain yang akan sering kita perbincangkan dalam penelitian ini adalah mengenai peranan matematika dalam aspek profesi. Salah satu alasan utama bahwa matematika sangat penting dalam dunia modern saat ini adalah bahwa hampir setiap profesi membutuhkan pengetahuan matematika. Meskipun banyak peranan matematika dalam segala aspek kehidupan, namun tidak semua orang menyadari kegunaannya. Timbul pertanyaan mengapa sadar akan kegunaan matematika itu penting?. Sadar akan kegunaan matematika akan mendorong seseorang untuk mempelajari matematika. Contohnya dalam dunia penerbangan, dalam pendidikannya, seorang calon pilot akan dihadapkan dengan rumus-rumus matematika dan fisika. Oleh karena itu, kandidat sekolah pilot harus memiliki kemampuan dasar di bidang matematika maupun fisika. Hal tersebut akan mendorong kandidat tersebut untuk menguasai matematika. Melalui analogi yang sama kita juga dapat mengatakan bahwa jika setiap siswa di sekolah menyadari akan kegunaan matematika dalam berbagai aspek kehidupan, maka tidak akan ada siswa yang membenci, malas belajar matematika dan tidak menguasai matematika. Oleh karena itu, sadar akan kegunaan matematika merupakan salah satu faktor kunci untuk menguasai matematika. Menurut hasil PISA tahun 2012, di semua negara yang ikut serta, siswa yang memiliki kesadaran matematis mendapat 18 angka lebih tinggi dalam ujian matematika. Keunggulan 18 angka menurut PISA setara dengan belajar matematika sekitar setengah tahun (PISA, 2012).

Uraian di atas, menjelaskan betapa pentingnya kesadaran matematis dimiliki oleh setiap siswa yang sedang belajar matematika. Melalui peningkatan kesadaran matematis, diharapkan 
kemampuan matematis siswa juga mengalami peningkatan. Hal ini sejalan dengan Permendiknas Nomor 22 Tahun 2006, para siswa seharusnya memiliki sikap menghargai kegunaan matematika dalam kehidupan, yaitu memiliki rasa ingin tahu, perhatian, dan minat dalam mempelajari matematika, serta sikap ulet dan percaya diri dalam pemecahan masalah. Namun fakta yang terjadi di lapangan adalah kurangnya kesadaran siswa akan kegunaan matematika dalam berbagai aspek kehidupan. Hal ini bertolak belakang dengan harapan yang telah diuraikan sebelumnya. Untuk mendukung fakta tersebut peneliti melakukan studi pendahuluan melalui pemberian angket yang bertujuan untuk mengetahui kesadaran siswa akan kegunaan matematika dalam kehidupan sehari-hari.

Hasil analisis yang peneliti lakukan menunjukkan seluruh siswa menyatakan setuju bahwa apapun pekerjaan mereka kelak matematika akan berguna ketika bekerja nanti. Namun terdapat hasil yang bertolak belakang dari pernyataan di atas. Sebagian besar siswa tidak setuju bahwa untuk melanjutkan studi ke perguruan tinggi, belajar matematika dari sekarang akan sangat membantu mempelajari bidang yang mereka minati kelak. Adapun beberapa alasan umum siswa yang tidak setuju akan kegunaan matematika pada pernyataan tersebut yaitu: (1) karena bidang yang mereka minati tidak ada hubungannya dengan matematika; (2) karena belum tentu masuk jurusan matematika; dan (3) karena tidak berminat masuk jurusan matematika.

Bila diselidiki lebih lanjut, siswa yang memberikan penjelasan nomor 1 terlihat belum memiliki kesadaran akan pengaplikasian matematika dalam segala aspek kehidupan. Contohnya, salah seorang siswa menjawab bahwa matematika tidak ada hubungan dengan minatnya dalam fotografi. Siswa tersebut tampak belum menyadari bahwa dalam fotografi ada konsep matematika yang digunakan dalam mengambil gambar. Misalnya konsep mengenai sudut dan kemiringan. Seorang fotografer belum tentu dapat menghasilkan gambar yang baik bila tidak mengambil gambar dalam sudut dan kemiringan yang tepat.

Siswa yang memberikan penjelasan nomor 2 menunjukkan bahwa dia belum memiliki kesadaran dalam belajar matematika. Berdasarkan penjelasan tersebut, tersirat bahwa siswa hanya belajar sesuai orientasi tujuan. Siswa tersebut hanya akan belajar sungguh-sungguh pada pelajaran yang dianggapnya akan berguna di kemudian hari. Siswa yang memberikan penjelasan nomor 3 menunjukkan bahwa dia belum memiliki kesadaran akan kegunaan matematika sebagai penunjang keberhasilan dalam mempelajari pengetahuan yang lainnya. 
Berdasarkan uraian di atas peneliti memperoleh kesimpulan bahwa kesadaran matematis memiliki peran penting dalam membentuk pola pikir, sikap dan prestasi belajar siswa dalam matematika, sehingga perlu dilakukan suatu upaya untuk menumbuhkan kesadaran tersebut.

Saat ini, pembelajaran dengan pendekatan scientific dinilai baik karena kegiatan pembelajaran di kelas berpusat pada siswa, namun yang yang menjadi permasalahan adalah mengenai bagaimana menerapkan pendekatan tersebut agar siswa dapat terlibat didalamnya. Penggunaan pendekatan scientific dalam kegiatan pembelajaran dapat melatih siswa untuk dapat menyesaikan masalah dengan menggunakan metode ilmiah. Belajar melalui metode ilmiah diyakini sebagai titian emas perkembangan sikap, keterampilan, dan pengetahuan peserta didik. Selain itu hasil penelitian membuktikan bahwa: "Pada pembelajaran tradisonal, retensi informasi dari guru sebesar 10\% setelah lima belas menit dan perolehan pemahaman kontekstual sebesar 25\%. Pada pembelajaran berbasis pendekatan ilmiah, retensi informasi dari guru sebesar lebih dari $90 \%$ setelah dua hari dan perolehan pemahaman kontekstual sebesar 50-70\% (Kemdikbud, 2013).

Pendekatan eksplorasi merupakan bagian dari pendekatan scientific yang memiliki karakteristik yang sama. Karena memiliki karakteristik yang sama, maka tujuan pembelajaran dengan pendekatan eksplorasi tidak jauh berbeda dengan pembelajaran dengan pendekatan scientific. Pendekatan ini dipilih karena proses untuk memperoleh pengetahuan dilakukan dengan mengikuti metode ilmiah. Pendekatan eksplorasi merupakan kegiatan memperoleh pengetahuan melalui proses mengumpulkan informasi, mengolah informasi, melakukan analisis untuk mencari suatu pola atau informasi khusus, membuat hipotesis, mencoba, kemudian menarik kesimpulan.

Penerapan pendekatan eksplorasi tidak semudah yang kita bayangkan. Sebagian besar guru yang bertugas merancang kegiatan pembelajaran pun belum begitu mengerti bagaimana cara merancang pembelajaran dengan menggunakan pendekatan eksplorasi. Hambatan lain yang dihadapi guru dalam penerapan pendekatan eksplorasi juga terletak pada siswanya. Tidak semua siswa dapat belajar matematika dengan baik ketika menggunakan pendekatan eksplorasi. Belajar dengan menggunakan pendekatan eksplorasi akan berjalan dengan baik jika siswa telah memiliki kemampuan matematika yang baik dan memiliki kesadaran belajar yang tinggi.

Usaha menumbuhkan kesadaran matematis siswa juga dapat dilakukan selama proses pembelajaran. Guru dapat menyisipkan hal-hal yang berkaitan dengan kegunaan matematika 
dalam bahan ajar matematika. Namun, agar siswa sadar akan kegunaan matematika yang diintegrasikan dalam bahan ajar, siswa harus terlibat dalam kegiatan pembelajaran. Ada suatu fakta yang pada kenyataannya sulit untuk dirubah mengenai karakteristik siswa di Indonesia. Sebagian besar proses untuk memperoleh pengetahuan merupakan hasil transfer langsung dari guru ke siswa. Siswa sudah terbiasa menerima, sehingga saat guru ingin melakukan perubahan dengan menuntut siswa lebih aktif dalam kegiatan pembelajaran sangatlah sulit (Handayani, 2020). Hal ini merupakan masalah klasik dalam pelaksanaan pembelajaran matematika di Indonesia yang hingga saat ini belum terselesaikan.

Kesadaran matematika merupakan salah satu faktor yang dapat meningkatkan prestasi belajar siswa. Meningkatkan kesadaran matematika sama saja dengan meningkatkan prestasi belajar siswa, terkadang meskipun kemampuan awal siswa tergolong rendah, namun jika siswa memiliki kesadaran akan pentingnya matematika, mereka akan memaksakan diri untuk mengerti pelajaran yang diajarkan. Seseorang yang memiliki minat lebih terhadap sesuatu biasanya akan melakukan berbagai macam cara untuk menekuni minatnya. Begitu pula dalam belajar matematika, ketika seorang siswa menyadari pentingnya belajar matematika, meskipun kemampuannya tergolong kurang, ia akan berusaha memahami pelajaran yang sedang diajarkan. Sama halnya dengan penerapan pendekatan eksplorasi, untuk mempermudah penerapan pembelajaran dengan menggunakan pendekatan eksplorasi, perlu dilakukan upaya agar siswa mau mengoptimalkan kemampuan guna meningkatkan kemampuan matematisnya. Oleh karena itu, dalam penelitian ini peneliti akan menggunakan model pembelajaran snow cube throwing yang sudah dianggap berhasil dalam menumbuhkan minat belajar siswa (Sari, 2010) dalam penerapan pembelajaran dengan pendekatan eksplorasi.

Model pembelajaran snow cube throwing merupakan pengembangan dari model pembelajaran snowball throwing. Pada penelitian selanjutnya, model pembelajaran ini dikembangkan dengan tujuan untuk membuat siswa berminat dalam belajar matematika dengan menggunakan pendekatan eksplorasi. Dengan menggunakan model pembelajaran ini, peneliti menduga bahwa siswa akan lebih tertarik, termotivasi serta dapat belajar dengan menggunakan pendekatan eksplorasi dalam suasana yang menyenangkan. Ketertarikan dan kesenangan, keduanya mempengaruhi tingkat keterlibatan siswa dalam belajar dan kedalaman pemahaman yang akan diperoleh (Schiefele, 2009). Suasana pembelajaran yang baik akan berimplikasi pada 
peningkatan hasil belajar siswa, sehingga bukan hal yang mustahil bahwa kemampuan matematis siswa juga akan meningkat.

Dalam pembelajaran snow cube throwing berbasis eksplorasi (SCTBE) siswa diberikan lima jenis bahan ajar berbeda untuk mempelajari suatu konsep matematika. Untuk mempelajari konsep tersebut, siswa diberikan beberapa masalah eksplorasi yang kontekstual, yang ditempelkan pada kubus, dimana pada setiap sisi kubus, siswa dituntut untuk memahami masalah, menemukan pola, membuat dugaan dan pada sisi kubus terakhir siswa diminta membuat kesimpulan mengenai konsep yang sedang dipelajari.

Masalah-masalah yang disajikan dalam pembelajaran snow cube throwing berbasis eksplorasi diantaranya merupakan masalah-masalah kontekstual yang berhubungan dengan penerapan matematika dalam kehidupan sehari-hari. Hal ini bertujuan untuk menumbuhkan kesadaran siswa akan pentingnya matematika dalam kehidupan sehari-hari. Stanic dan Kilpatrick (1989) berpendapat bahwa masalah yang disajikan sesuai dengan pengalaman di dunia nyata akan meyakinkan siswa dan guru tentang nilai kegunaan matematika. Berdasarkan pendapat tersebut, diharapkan melalui pemberian masalah kontekstual akan muncul kesadaran siswa akan kegunaan matematika dalam kehidupan sehari-hari.

\section{METODE PENELITIAN}

Penelitian ini merupakan penelitian mix-method. Penelitian metode campuran adalah kelas dalam penelitian dimana peneliti mencampur atau menggabungkan kuantitatif dan kualitatif, teknik penelitian, metode, pendekatan, konsep atau bahasa dalam satu penelitian atau serangkaian penelitian terkait (Johnson \& Onwuegbuzie, 2007). Data kuantitatif dalam penelitian ini adalah hasil angket kesadaran matematis yang diberikan setelah pembelajaran. Data kualitatif dalam penelitian ini dikumpulkan melalui hasil wawancara. Adapun perlakuan yang diberikan adalah pembelajaran Snow Cube Throwing berbasis eksplorasi (SCTBE).

Desain yang digunakan dalam penelitian campuran ini adalah rancangan sekuensial eksplanatoris. Menurut Creswell \& Clark (Creswell, 2015) rancangan sekuensial eksplanatoris disebut juga model dua fase yang pertama-tama dilakukan dengan mengumpulkan data kuantitatif dan setelah itu mengumpulkan data kualitatif untuk membantu menjelaskan atau mengelaborasi tentang hasil kuantitatif. 
Data kuantitatif dalam penelitian ini diperoleh dengan menggunakan rancangan perbandingan kelompok statik. Kelompok pertama memperoleh pembelajaran SCTBE pada sekolah kategori atas $\left(\mathrm{X}_{1}\right)$, kelompok kedua memperoleh pembelajaran SCTBE pada sekolah kategori tengah $\left(\mathrm{X}_{2}\right)$, dan kelompok ketiga memperoleh pembelajaran SCTBE pada kategori sekolah bawah $\left(\mathrm{X}_{3}\right)$

$$
\begin{array}{cc}
\mathrm{X}_{1} & \mathrm{O} \\
\hdashline \mathrm{X}_{2} & \mathrm{O} \\
\hline \mathrm{X}_{3} & \mathrm{O}
\end{array}
$$

Keterangan :

$\mathrm{O}$ : Post-response dari hasil angket kesadaran matematis

Penelitian ini dilaksanakan di tiga sekolah menengah pertama negeri di Kota Cimahi. sekolah menengah pertama swasta tidak masuk dalam populasi penelitian dikarenakan sulitnya memperoleh informasi mengenai kategori sekolah pada sekolah-sekolah tersebut. Tujuan pengelompokan siswa ke dalam beberapa kategori sekolah didasarkan karena setiap sekolah memiliki ciri khas pembelajaran dan karakteristik siswa yang berbeda. Berdasarkan tujuan tersebut, dimungkinkan bahwa penerapan model pembelajaran SCTBE akan memberikan dampak kesadaran matematis yang berbeda pada setiap kategori sekolah. Pengelompokan sekolah ke dalam beberapa kategori sekolah dibagi menjadi kategori atas, tengah dan bawah.

Pemilihan sampel dalam penelitian ini didasarkan pada tehnik strata (stratified random sampling) serta teknik kelompok (group level random sampling). Teknik strata digunakan peneliti saat memilih tiga sekolah dari tiga kategori sekolah yang ada, pada masing-masing kategori sekolah atas, tengah dan bawah diundi satu sekolah, sedangkan tehnik kelompok digunakan saat peneliti memilih secara diundi satu kelas dari setiap sekolah. Subjek yang dipilih dalam wawancara terdiri dari 9 siswa yang berasal dari 3 kelas penelitian, dimana pada masingmasing kelas penelitian diambil 3 orang siswa dengan kategori siswa yang memiliki kemampuan matematis tinggi dan sedang dan rendah. Pemilihan siswa berdasarkan tingkat kemampuannya didasarkan pada keterwakilan jawaban yang ingin diperoleh peneliti.

Instrumen yang digunakan untuk mengumpulkan data dalam penelitian ini yaitu instrument non tes angket kesadaran matematis. Angket kesadaran matematis yang digunakan dalam penelitian ini diadaptasi dari instrumen non tes pada PISA dan ATMI tahun 2012 untuk mengukur motivasi instrumental siswa. Angket ini disusun dengan mengembangkan 4 indikator 
yang ada. Jumlah pernyataan dalam angket tersebut terdiri dari 10 pernyataan. Angket yang dimaksud dipaparkan sebagai berikut:

Tabel 1. Indikator Kesadaran Matematis

\begin{tabular}{|c|c|c|}
\hline Indikator & Pernyataan & $\begin{array}{l}\text { No. } \\
\text { soal }\end{array}$ \\
\hline $\begin{array}{l}\text { Matematika membantu } \\
\text { mereka dalam melakukan } \\
\text { pekerjaan nanti }\end{array}$ & $\begin{array}{ll}\text { - } & \text { Apapun pekerjaan saya kelak, matematika akan selalu berguna ketika saya bekerja nanti. } \\
\text { - } & \text { Ada pekerjaan yang tidak membutuhkan pengetahuan dan keterampilan matematika. } \\
\text { - } & \text { Matematika dapat dipelajari secara mandiri ketika terjun di dunia kerja. Jadi, mempelajari } \\
\text { matematika dari sekarang tidak berguna. }\end{array}$ & 1 \\
\hline & & 10 \\
\hline $\begin{array}{l}\text { Matematika meningkatkan } \\
\text { prospek karir dan peluang } \\
\text { bekerja }\end{array}$ & $\begin{array}{l}\text { - Saya akan mendapatkan pekerjaan yang lebih baik, jika memiliki prestasi yang baik } \\
\text { dalam matematika. } \\
\text { Kemampuan matematika yang baik tidak menjamin seseorang akan memiliki karir yang } \\
\text { baik. } \\
\text { - Dalam tes penempatan bekerja, kemampuan matematika yang baik menjadi salah satu } \\
\text { faktor yang menentukan posisi pekerjaan. }\end{array}$ & 2 \\
\hline $\begin{array}{l}\text { Matematika dibutuhkan } \\
\text { untuk mempelajari sesuatu } \\
\text { di kemudian hari }\end{array}$ & $\begin{array}{l}\text { - Ketika saya melanjutkan studi ke perguruan tinggi, mempelajari matematika dari } \\
\text { sekarang akan membantu saya mempelajari bidang yang saya minati kelak. } \\
\text { - Untuk mempelajari suatu keterampilan ataupun pengetahuan, kemampuan matematis } \\
\text { yang baik tidak selalu dibutuhkan. }\end{array}$ & 3 \\
\hline $\begin{array}{l}\text { Matematika membantu } \\
\text { mendapatkan pekerjaan }\end{array}$ & $\begin{array}{l}\text { - Saya akan mudah memperoleh pekerjaan jika saya terampil dalam matematika. } \\
\text { - Mempelajari bahasa inggris akan lebih meningkatkan peluang untuk mendapatkan } \\
\text { pekerjaan dibandingkan mempelajari matematika. }\end{array}$ & 4 \\
\hline
\end{tabular}

Karena yang digunakan merupakan hasil adaptasi, maka pada angket ini penimbang hanya diminta saran dan masukan mengenai validitas muka angket tersebut. Skala Likert digunakan untuk mengukur kesadaran matematis siswa yang memperoleh pembelajaran SCTBE pada setiap kategori sekolah. Simbol SS (sangat setuju), S (Setuju), TS (Tidak Setuju) dan STS (Sangat Tidak Setuju). Jawaban siswa pada setiap pernyataan akan diberikan skor. Pemberian skor tergantung pada jenis pernyataannya. Apabila pernyataan tersebut positif, $\mathrm{SS}=4, \mathrm{~S}=3$, TS $=2$ dan $\mathrm{STS}=1$, sedangkan untuk pernyataan negatif, $\mathrm{SS}=1, \mathrm{~S}=2, \mathrm{TS}=3$, dan $\mathrm{STS}=4$.

Berdasarkan jawaban siswa, selanjutnya akan diperoleh kecenderungan atas jawaban siswa tersebut. Perhitungan indeks jawaban siswa untuk pernyataan positif dilakukan dengan rumus sebagai berikut: Nilai Indeks $=\left(\left(F_{1} \times 1\right)+\left(F_{2} \times 2\right)+\left(F_{3} \times 3\right)+\left(F_{4} \times 4\right)\right) / 4$, Sedangkan untuk pernyataan negatif, dilakukan dengan rumus sebagai berikut: Nilai Indeks = $\left(\left(\mathrm{F}_{4} \times 1\right)+\left(\mathrm{F}_{3} \times 2\right)+\left(\mathrm{F}_{2} \times 3\right)+\left(\mathrm{F}_{1} \times 4\right)\right) / 4$

\section{Keterangan :}

$\mathrm{F}_{1}$ adalah frekuensi jawaban siswa yang menjawab Sangat Tidak Setuju

$\mathrm{F}_{2}$ adalah frekuensi jawaban siswa yang menjawab Tidak Setuju

$\mathrm{F}_{3}$ adalah frekuensi jawaban siswa yang menjawab Setuju

$\mathrm{F}_{4}$ adalah frekuensi jawaban siswa yang menjawab Sangat Setuju 
Kriteria 3 kotak (three box method) digunakan dalam menghitung rentang indeks, apakah termasuk kategori rendah, sedang, tinggi. Cara menghitung rentang indeks adalah dengan cara menghitung selisih antara (jumlah siswa $\times$ skor terendah) dengan (jumlah siswa $\times$ skor tertinggi). Rentang indeks tersebut kemudian dibagi 3 kategori. Untuk lebih jelas, penghitungan rentang indeks pada setiap kategori sekolah kelompok SCTBE adalah sebagai berikut.

Tabel 2. Hasil Perhitungan Rentang Indeks pada Setiap Kategori Sekolah

\begin{tabular}{cccccc}
\hline $\begin{array}{c}\text { Kategori } \\
\text { Sekolah }\end{array}$ & $\begin{array}{c}\text { Jumlah } \\
\text { Siswa }\end{array}$ & $\begin{array}{c}\text { Indeks } \\
\text { Terendah }\end{array}$ & $\begin{array}{c}\text { Indeks } \\
\text { Terendah }\end{array}$ & $\begin{array}{c}\text { Rentang } \\
\text { Indeks }\end{array}$ & Kategori \\
\hline Atas & 29 & 29 & 116 & 87 & $\begin{array}{l}29-58=\text { Rendah } \\
59-87=\text { Sedang } \\
88-116=\text { Tinggi }\end{array}$ \\
\hline \multirow{2}{*}{ Tengah } & \multirow{2}{*}{32} & \multirow{2}{*}{32} & \multirow{2}{*}{128} & 96 & $\begin{array}{l}32-64=\text { Rendah } \\
65-96=\text { Sedang } \\
97-128=\text { Tinggi }\end{array}$ \\
\hline \multirow{2}{*}{ Bawah } & \multirow{2}{*}{31} & \multirow{2}{*}{31} & \multirow{2}{*}{124} & \multirow{2}{*}{93} & $\begin{array}{l}31-62=\text { Rendah } \\
63-93=\text { Sedang } \\
94-124\end{array}$ \\
& & & & & Tinggi \\
\hline
\end{tabular}

Analisis data kuantitatif digunakan untuk mengkaji perbedaan kesadaran matematis siswa yang memperoleh pembelajaran SCTBE ditinjau dari kategori sekolah. Sebelum dilakukan uji rerata, dilakukan terlebih dahulu uji asumsi sebagai dasar dalam pengujian hipotesis yaitu uji normalitas masing-masing kelompok dan uji homogenitas varians. Dalam penelitian ini, uji perbedaan rerata antar kelompok data dilakukan dengan menggunakan uji Kruskall Walis.

\section{HASIL DAN PEMBAHASAN}

Snow cube throwing merupakan gabungan dari dua buah kata asing yaitu snow cube dan throwing. Snow cube dalam bahasa Indonesia berarti kubus salju, dan throwing dalam bahasa Indonesia berarti melempar. Jika kedua kata tersebut digabungkan akan membentuk sebuah kalimat yang memiliki arti "melempar kubus salju”. Oleh karena itu, snow cube throwing dapat diartikan sebagai model pembelajaran dengan melemparkan kubus salju. Model pembelajaran ini merupakan pengembangan dari model pembelajaran snowball throwing.

Terdapat beberapa perbedaan antara kedua model pembelajaran tersebut. Jika dalam model pembelajaran Snowball Throwing media yang digunakan adalah kertas yang dibuat menyerupai bola, sedangkan dalam model pembelajaran snow cube throwing media yang digunakan adalah kubus. Kubus yang digunakan dalam pembelajaran tersebut ialah kubus yang 
terbuat dari karton tebal dan terdiri dari 6 buah pertanyaan eksplorasi dengan masalah kontekstual sesuai dengan jumlah sisi pada kubus tersebut. Perbedaan lainnya yaitu, dalam model pembelajaran snowball throwing soal-soal yang dikerjakan oleh siswa dibuat oleh siswa itu sendiri sedangkan pada model pembelajaran snow cube throwing persoalan-persoalan yang dikerjakan oleh siswa dirancang oleh guru. Persoalan matematika dalam pembelajaran ini terdiri dari persoalan eksplorasi dengan masalah kontekstual. Salah satu persamaan dari kedua model pembelajaran tersebut adalah pada kegiatan melempar.

Penerapan model pembelajaran ini salah satunya ditujukan agar terjadi peningkatan kesadaran matematis siswa akan kegunaan matematika. Oleh karena dalam studi ini akan dipaparkan hasil penelitian terkait yang menunjukkan perbandingan kesadaran matematis siswa yang sama-sama menggunakan model pembelajaran snow cube throwing di kategori level sekolah yang berbesa. Deskripsi rataan dan deviasi standar data Kesadaran Matematis (KM) siswa dari ketiga kelompok tersebut disajikan pada Tabel 3.

Tabel 3. Deskripsi KM Siswa Kelas SCTBE Berdasarkan Kategori Sekolah

\begin{tabular}{lll}
\hline Kategori Sekolah & Statistik & Kelas SCTBE \\
\hline \multirow{3}{*}{ Atas } & Rataan & 24,69 \\
& Simp. Baku & 5,37 \\
& Jumlah Siswa & 29 \\
\hline \multirow{2}{*}{ Tengah } & Rataan & 26,54 \\
& Simp. Baku & 4,80 \\
& Jumlah Siswa & 32 \\
\multirow{3}{*}{ Bawah } & Rataan & 24,60 \\
& Simp. Baku & 3,39 \\
\hline
\end{tabular}

Berdasarkan data pada Tabel 3 dapat dibuat diagram yang menggambarkan perbandingan rataan KM siswa kelas SCTBE berdasarkan Kategori sekolah, seperti yang dimuat pada Gambar 1. 


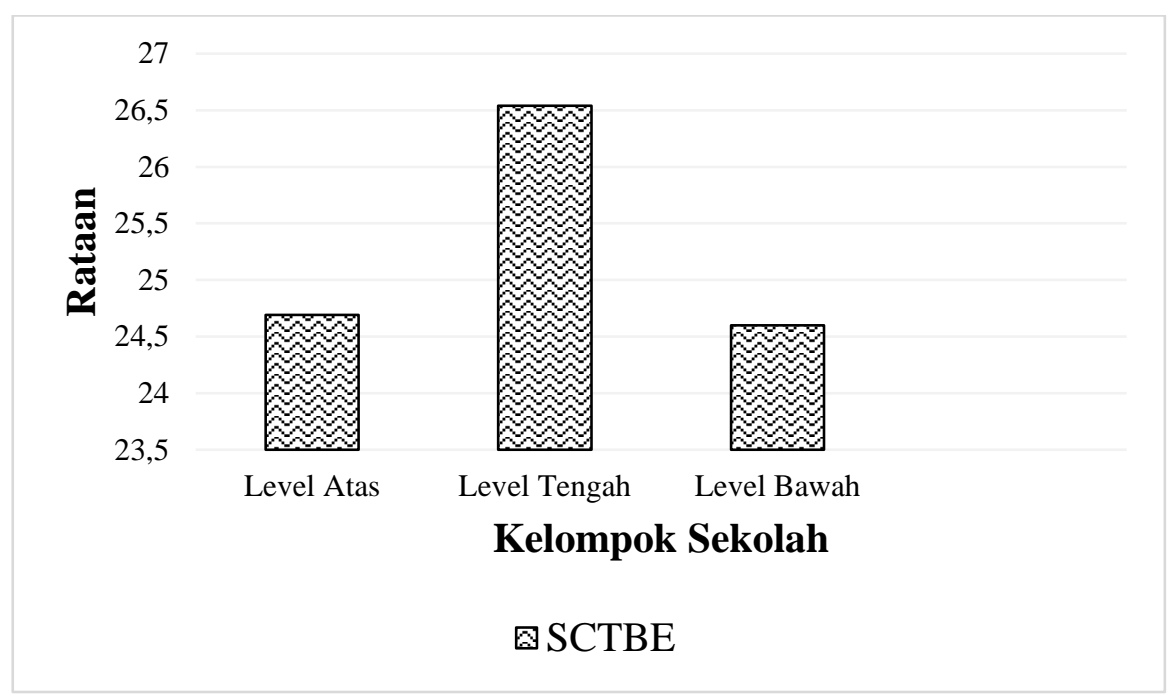

Gambar 1. Perbandingan Rataan KM Siswa berdasarkan Kategori Sekolah

Dari data yang termuat pada Tabel 3 dan diagram pada Gambar 1 diperoleh informasi bahwa rataan KM siswa kelompok SCTBE kategori tengah lebih tinggi dari rataan KM siswa kelompok SCTBE pada kategori sekolah atas dan bawah. Rataan kelompok SCTBE kategori atas terlihat tidak jauh berbeda bila dibandingkan kelompok SCTBE Kategori bawah.

Deskripsi data yang terdapat pada Tabel 3, juga mengungkapkan adanya perbedaan rataan KM siswa kelompok SCTBE antar kategori sekolah. Data pada Tabel 4 akan menunjukkan selisih rataan KM siswa yang memperoleh pembelajaran SCTBE antar kategori sekolah.

Tabel 4. Selisih Rataan KM Siswa Kelas SCTBE

\begin{tabular}{llll}
\hline Kategori Sekolah & Atas & Tengah & Bawah \\
\hline Atas & - & $-1,85$ & 0,09 \\
Tengah & 1,85 & - & 1,94 \\
Bawah & $-0,09$ & $-1,94$ & - \\
\hline
\end{tabular}

Untuk melihat apakah KM siswa yang memperoleh pembelajaran SCTBE antar kategori sekolah berbeda atau tidak, diawali dengan melihat perbedaan KM siswa kelompok SCTBE pada ketiga kategori sekolah. Untuk keperluan tersebut, diawali dengan melakukan uji normalitas data ketiga kelompok data.

Berdasarkan hasil analisis uji normalitas diperoleh informasi bahwa nilai probabilitas sig. untuk kategori sekolah atas adalah 0,200, kategori sekolah tengah adalah 0,200 dan kategori sekolah bawah adalah 0,200. Memperhatikan nilai sig. yang diperoleh pada setiap kategori sekolah lebih besar dari 0,05, maka $\mathrm{H}_{\mathrm{o}}$ diterima. Dengan demikian dapat disimpulkan bahwa 
data KM siswa kelompok SCTBE pada setiap kategori sekolah berdistribusi normal. Karena KM siswa kelompok SCTBE pada setiap kategori sekolah berdistribusi normal, selanjutnya dilakukan uji homogenitas ketiga kelompok data. Hasil analisis uji homogenitas diperoleh informasi bahwa nilai sig adalah 0,028. Dengan demikian dapat disimpulkan bahwa varians data KM siswa kelompok SCTBE pada setiap kategori sekolah tidak homogen. Oleh karena itu uji yang digunakan untuk menguji perbedaan rataan peningkatan KM siswa SCTBE pada ketiga kategori sekolah, digunakan uji Kruskal Walis dengan hipotesis sebagai berikut:

$\mathrm{H}_{\mathrm{o}} \quad: \mu_{1}=\mu_{2}=\mu_{3}$

$\mathrm{H}_{1} \quad$ : paling sedikit salah satu rata-rata berbeda dengan yang lainnya.

Keterangan: $\mu_{1}, \mu_{2}, \mu_{3}$ berturut-turut adalah rataan peningkatan KM siswa pada kategori sekolah atas, tengah dan bawah yang memperoleh pembelajaran SCTBE. Hasil perhitungan uji Kruskall Walis dimuat pada Tabel 5.

Tabel 5. Uji Perbedaan KM

\begin{tabular}{llll}
\hline Perbandingan Rerata KM & $\begin{array}{l}\text { Chi- } \\
\text { Square }\end{array}$ & Sig. & Kesimpulan \\
\hline $\begin{array}{l}\text { SCTBE Kategori Atas : SCTBE Kategori Tengah : SCTBE } \\
\text { Kategori Bawah }\end{array}$ & 3,064 & 0,216 & Terima $\mathrm{H}_{\mathrm{o}}$ \\
\hline
\end{tabular}

Berdasarkan Tabel 5 diperoleh informasi bahwa kesimpulan analisis data adalah $\mathrm{H}_{\mathrm{o}}$ diterima. Dengan demikian disimpulkan tidak terdapat perbedaan rataan KM siswa yang signifikan pada ketiga kategori sekolah yang memperoleh pembelajaran SCTBE. Artinya, pembelajaran SCTBE memberikan dampak yang sama terhadap kesadaran matematis siswa pada setiap kategori sekolah. Dengan kata lain, seluruh siswa yang memperoleh pembelajaran SCTBE memiliki kesadaran yang sama akan kegunaan matematika dalam kehidupan seharihari, studi masa depan dan juga karir. Hasil tersebut sejalan dengan penelitian Chisholm (Yacovelli, 2005) data dari studinya menyarankan bahwa terdapat lima variabel yang dapat membantu siswa untuk tidak menghindari matematika salah satunya adalah dengan mengubah persepsi siswa terhadap kegunaan matematika. Berdasarkan studi literatur yang dilakukan Larsen (2013) beberapa faktor telah ditemukan untuk mempengaruhi stabilitas sikap seperti lingkungan belajar, kualitas guru, dan metode pengajaran bermakna. Selanjutnya, Townsend \& Wilton (2003) menemukan dukungan bagi teori yang sikap terhadap matematika, meskipun resisten terhadap perubahan, dapat ditingkatkan melalui penggunaan metode pembelajaran 
kooperatif. Dalam hal ini, model pembelajaran snow cube throwing merupakan model pembelajaran dengan setting kooperatif, dimana siswa berkelompok dengan teman sebangkunya dalam menyelesaikan masalah matematis yang diberikan. Paparan di atas, mendukung hasil penelitian yang mengungkapkan bahwa model pembelajaran snow cube throwing dapat menumbuhkan kesadaran matematis siswa.

Untuk melihat dampak pembelajaran SCTBE terhadap kesadaran matematis siswa, dilakukan analisis terhadap setiap indikator kesadaran matematis siswa. Kesadaran matematis siswa yang diamati dalam penelitian ini terdiri dari 4 indikator. Berikut akan dipaparkan hasil perhitungan rata-rata nilai indeks angket kesadaran matematis siswa kelompok SCTBE pada setiap kategori sekolah berdasarkan indikator kesadaran matematis. Hasil Perhitungan disajikan secara ringkas pada Tabel 6 di bawah ini.

Tabel 6. Rata-Rata Nilai Indeks Angket KM

\begin{tabular}{clccc}
\hline Indikator & Nomor & \multicolumn{3}{c}{ Rata-Rata Nilai Indeks Kelompok SCTBE } \\
\cline { 3 - 5 } & Pernyataan & Kategori Atas & Kategori Tengah & Kategori Bawah \\
\hline 1 & 1,5 dan 10 & 89 & 106 & 92 \\
2 & 2,7 dan 9 & 86,3 & 92,6 & 87 \\
3 & 3 dan 8 & 89,5 & 91 & 84,5 \\
4 & 4 dan 6 & 84,5 & 66,5 & 83 \\
\hline
\end{tabular}

Berdasarkan pernyataan pada setiap indikator, siswa kelompok SCTBE pada sekolah kategori atas dan tengah memiliki kesadaran matematis yang tinggi dalam kesadaran bahwa matematika membantu mereka dalam melakukan pekerjaan mereka nanti, sedangkan kesadaran matematis siswa SCTBE pada sekolah kategori bawah termasuk pada kategori sedang. Pernyataan tersebut sejalan dengan hasil wawancara yang menunjukkan bahwa sikap siswa terhadap matematika dipengaruhi oleh cita-cita atau apa yang akan dilakukannya dikemudian hari. Mereka telah memiliki kesadaran yang tinggi bahwa matematika akan berguna dikemudian hari, sehingga hal tersebut diharapkan akan berdampak positif terhadap sikap siswa dalam belajar matematika.

Pada indikator kedua, siswa kelompok SCTBE pada sekolah kategori atas, tengah dan bawah termasuk pada kategori sedang dalam hal menyadari bahwa matematika meningkatkan prospek karir dan peluang bekerja. Pada pernyataan ini, tidak semua siswa menyadari bahwa matematika akan meningkatkan peluang untuk mendapatkan pekerjaan. Ada sebagian siswa berpendapat bahwa tanpa mempelajari matematika mereka akan mendapatkan pekerjaan yang 
baik. Beberapa siswa bahkan berpendapat bahwa mempelajari pelajaran lain, misalnya Bahasa Inggris lebih meningkatkan prospek karir atau peluang bekerja.

Hasil analisis terhadap indikator ketiga menunjukkan bahwa siswa kelompok SCTBE pada sekolah kategori atas memiliki kesadaran matematis yang tinggi dalam kesadaran bahwa matematika dibutuhkan untuk mempelajari sesuatu dikemudian hari, namun pada siswa SCTBE pada sekolah kategori tengah dan bawah, kesadaran tersebut termasuk pada kategori sedang. Pernyataan tersebut sesuai dengan hasil wawancara dengan beberapa perwakilan siswa yang menyatakan bahwa apapun cita-citanya kelak, belajar matematika sejak dini akan membantu pekerjaan yang akan digelutinya nanti. Meskipun sebagian besar siswa menyatakan bahwa matematika berguna untuk mempelajari apa yang akan dilakukannya dikemudian hari, beberapa siswa justru menyatakan bahwa matematika tidak berguna bagi pekerjaan yang dicitacitakannya. Hal ini bertolak belakang dengan pendapat Nickerson (2011) yang mengungkapkan bahwa setidaknya terdapat empat alasan kenapa harus belajar matematika pada tingkat SMA. Pertama, belajar matematika penting untuk siswa yang ingin mempelajari matematika ke jenjang yang lebih tinggi. Kedua, mengubah kebiasaan pikiran sehingga siswa menjadi kritis, dengan cara yang konstruktif, ketiga, memperkaya kehidupan intelektual seseorang serta berguna dalam praktik kehidupan sehari hari. Keempat, ada banyak kesenangan yang didapat dalam mempelajari matematika.

Hasil analisis terhadap indikator keempat menunjukkan bahwa kesadaran matematis siswa SCTBE pada sekolah kategori atas, tengah dan bawah termasuk pada kategori sedang dalam hal menyadari bahwa matematika membantu mendapatkan pekerjaan. Dalam beberapa tes masuk ke sebuah lembaga ataupun perusahaan tes masuk biasanya merupakan tes yang terdiri dari hitung-hitungan dasar. Bahkan tes matematika juga biasanya digunakan sebagai penentu dalam pemilihan pegawai tetap di suatu perusahaan. Kurangnya kesadaran beberapa siswa akan hal tersebut mungkin disebabkan karena kurangnya pengetahuan akan kegunaan matematika dalam memperoleh pekerjaan. Padahal menurut Cajori (1893) dalam bukunya sejarah klasik matematika, bahwa "hampir tidak ada yang pernah dilakukan dalam matematika telah terbukti tidak berguna ". Oleh karena itu diperlukan kesadaran akan kegunaan matematika, sehingga semua orang menyadari akan pentingnya belajar matematika.

Secara umum, berdasarkan hasil analisis pada setiap indikator, kesadaran matematis siswa sudah tergolong baik. Sebagian besar siswa menyadari kegunaan matematika dalam 
kehidupan sehari-hari. Meskipun banyak faktor yang mempengaruhi kesadaran siswa tersebut, namun pemberian model pembelajaran yang menarik bisa menjadi salah satu faktor yang mempengaruhi kesadaran tersebut. Dalam pembelajaran snow cube throwing berbasis eksplorasi, siswa diberikan bahan ajar yang kontekstual. Hal ini dimaksudkan agar siswa mengetahui banyak sekali kegunaan dan penerapan konsep matematika dalam kehidupan seharihari.

Disamping itu, proses pembelajaran SCTBE dirancang agar siswa terlibat dalam kegiatan pembelajaran. Temuan penelitian yang dilakukan (Noddings, 1995) menunjukkan bahwa guru yang efektif memfasilitasi pembelajaran dengan benar-benar peduli dengan keterlibatan siswa mereka dan menciptakan atmosfir yang tepat yang meningkatkan pembelajaran siswa. Hasil penelitian tersebut mendukung dilaksanakannya pembelajaran SCTBE didalam kelas karena pembelajaran tersebut dapat menciptakan atmosfer yang baik selama pembelajaran. Selain berdasarkan hasil analisis terhadap angket terbuka yang diberikan pada siswa, sebagian besar siswa menyatakan bahwa mereka senang belajar menggunakan model SCTBE. Mensah, Okyere, \& Kuranchie (2013) berpendapat bahwa penting bagi guru matematika untuk mengembangkan sikap positif terhadap subjek dan membuat Matematika. Guru matematika harus menciptakan lingkungan yang menarik dan tidak mengancam di kelas dan menggunakan model untuk pembelajaran yang membuat siswa antusias dalam belajar. Ini mungkin akan membantu siswa mengembangkan sikap positif terhadap subjek, mempelajarinya tanpa hambatan dan karenanya meningkatkan kinerjanya.

\section{KESIMPULAN}

Pembelajaran SCTBE memberikan dampak yang sama terhadap kesadaran matematis siswa pada setiap kategori sekolah. Dengan kata lain, seluruh siswa yang memperoleh pembelajaran SCTBE memiliki kesadaran yang sama akan kegunaan matematika dalam kehidupan sehari-hari, studi masa depan dan juga karir. Pembelajaran SCTBE dapat mengubah sikap siswa menjadi lebih positif dan menghargai kegunaan matematika dalam kehidupan sehari-hari. Berdasarkan hasil analisis pada setiap indikator, kesadaran matematis siswa sudah tergolong baik. Sebagian besar siswa menyadari kegunaan matematika dalam kehidupan seharihari. Meskipun banyak faktor yang mempengaruhi kesadaran siswa tersebut, namun pemberian model pembelajaran yang menarik bisa menjadi salah satu faktor yang mempengaruhi kesadaran 
tersebut. Dalam pembelajaran snow cube throwing berbasis eksplorasi, siswa diberikan bahan ajar yang kontekstual. Hal ini dimaksudkan agar siswa mengetahui banyak sekali kegunaan dan penerapan konsep matematika dalam kehidupan sehari-hari.

\section{REFERENSI}

Cajori, F. (1980). A history of mathematics. Chelsea Reprint, 1985, 1991.

Creswell, J. W., \& Creswell, J. D. (2015). Research design: qualitative, quantitative, and mixed methods approaches. Sage publications.

Elfiky, I. (2009). Terapi berpikir positif. Penerbit Zaman.

Handayani, U. F. (2020). Analisis hambatan penerapan model pembelajaran kooperatif pada pelajaran matematika. Jurnal Pusaka, 9(2), 22-36.

Johnson, R. B., Onwuegbuzie, A. J., \& Turner, L. A. (2007). Toward a definition of mixed methods research. Journal of Mixed Methods Research, 1(2), 112-133.

Kemdikbud. (2013). Diktat guru dalam rangka implementasi kurikulum 2013.

Larsen, J. (2013). Attitude in mathematics: a thematic literature review. British Columbia: Simon Fraser University.

Mensah, J. K., Okyere, M., \& Kuranchie, A. (2013). Student attitude towards mathematics and performance: does the teacher attitude matter. Journal of Education and Practice, 4(3), 132-139.

Nickerson, R. (2011). Mathematical reasoning: patterns, problems, conjectures, and proofs. Taylor \& Francis.

Noddings, N. (1995). Teaching themes of care. Phi delta kappan, 76(9), 675.

PISA. (2012). Students'engangement, drive and self-beliefs. [online]. Diakses dari http://www.oecd.org/pisa/keyfindings/PISA-2012-results-volume-III.pdf.

Sari, N. M. (2010). Pengaruh model pembelajaran snow cube throwing terhadap hasil belajar dan minat siswa. (Skripsi). Universitas Pasundan, Bandung.

Schiefele, U. (2009). Situational and individual interest. Handbook of motivation at school, 197-222.

Stanic, G., \& Kilpatrick, J. (1989). Historical perspectives on problem solving in the mathematics curriculum. The Teaching and Assessing of Mathematical Problem Solving, 3, 1-22.

Townsend, M., \& Wilton, K. (2003). Evaluating change in attitude towards mathematics using the 'then-now'procedure in a cooperative learning programme. British Journal of Educational Psychology, 73(4), 473-487.

Yacovelli, S. (2005). Will they like it or use it?. Universal-Publishers. 